minos. Además, demuestra que la participación comunitaria puedes ser de gran ayuda para mapear y caracterizar la diseminación de los triatominos en extensas zonas y para identificar los factores de riesgo en las viviendas y sus alrededores. Estos resultados son de particular interés no solo para Colombia, sino también para otros países vecinos donde habitan los mismos vectores y las viviendas tienen características similares. (Campbell-Lendrum DH, Angulo VM, Esteban L, Tarazona Z, Parra GJ, Restrepo $\mathrm{M}$, et al. House-level risk factors for triatomine infestation in Colombia. Intl J Epidemiol. 2007; 36(4):866-72.)

\section{La gripe en Estados Unidos de 2006 a 2007 y la vacuna para 2007 a 2008}

En el período del 1 octubre de 2006 al 19 de mayo de 2007, la OMS y sus laboratorios colaboradores en los Estados Unidos (Sistema Nacional de Vigilancia de Virus Respiratorios y Entéricos) examinaron 179268 especímenes de virus y 23753 $(13,2 \%)$ dieron resultados positivos de gripe. De estos, $18817(79,2 \%)$ correspondieron al serotipo A y $4936(20,8 \%)$, al B. La proporción de positivos sobrepasó el 10\% la semana que terminó el 23 de diciembre de 2006, llegó al máximo de $28,6 \%$ en la semana que terminó el 10 de febrero de 2007 y bajó a menos de $10 \%$ en la semana que terminó el 28 de abril de 2007. Durante las tres temporadas anteriores, el porcentaje de especímenes positivos osciló de $22,6 \%$ a 34,7\% y el valor máximo se manifestó desde principios de diciembre hasta marzo. Durante 13 a 17 semanas consecutivas hubo más de $10 \%$ de resultados positivos, pero el porcentaje de defunciones por gripe y neumonía permaneció por debajo de los valores iniciales. Los virus A (H1) predominaron en esa temporada, si bien los A (H3) se aislaron con mayor frecuencia desde principios de marzo y predominaron en muchos países europeos y asiáticos.

En los Estados Unidos, los epidemiólogos informan de la distribución de la gripe en su propio estado o territorio mediante un código de actividad semanal de la enfermedad. Su mayor difusión se notó en la octava semana de 2007, cuando se extendió a 25 estados y 19 notificaron actividad regional. En 41 estados hubo actividad gripal dispersa por lo menos en una ocasión durante la temporada, pero en las semanas 16 a 20 de 2007 (en abril y mayo) la actividad de la gripe disminuyó. Durante las tres temporadas anteriores, el mayor número de estados informantes había variado de 41 a 50 . La mayor parte de los virus A (H1) se caracterizaron como A/Nueva Caledonia/20/99, que fue el componente de A (H1N1) recomendado para la vacuna de 200607. La mitad de los virus B del linaje B/Victoria se caracterizaron como B/Ohio/01/2005, el cual antigénicamente equivale al B/Malasia/2506/2004, componente $\mathrm{B}$ recomendado para la misma vacuna.

En los primeros meses de la temporada 200607, la mayor parte de los aislados A (H3) eran próximos a la cepa A/Wisconsin/67/2005, la A (H3N2) recomendada para inclusión en la vacuna. A fines de febrero de 2007, la mayor parte de aislados A (H3) mostraban títulos reducidos con antisueros producidos contra la cepa A/Wisconsin/67/2005.

En mayo de 2007, los Centros para el Control y la Prevención de Enfermedades (CDC) difundieron el aviso de la Red de Alerta de Salud de que había aumentado el número de defunciones pediátricas asociadas con gripe y coinfección por Staphylococcus aureus. En 2004-05 hubo solo una defunción pediátrica por esa causa, pero en 2005-06 se supo de tres defunciones. Durante el período del 1 de octubre de 2006 al 19 de mayo de 2007 ocurrieron 68 muertes infantiles asociadas con infecciones gripales, de las cuales 21 eran coinfecciones de gripe con S. aureus, tanto resistente como sensible a la meticilina.

En junio de 2007, en la reunión anual del Consejo de Epidemiólogos Estatales y Territoriales (CSTE), se ratificó la obligatoriedad de notificar al Sistema Nacional de Vigilancia de las Enfermedades las infecciones humanas por virus A novedosos. Estos se definieron como virus aislados de personas pero subtipificados como no humanos o virus que no pueden subtipificarse con los métodos estándar. Virus novedosos transmisibles de persona a persona podrían significar el principio de una pandemia y su pronta detección y caracterización aceleraría la ejecución de medidas protectoras de salud pública. También se mantuvo obligatoria la notificación al Sistema de Vigilancia de muertes pediátricas relacionadas con la gripe. Asimismo, los CDC siguen recomendando una vigilancia intensificada para detectar cualquier caso posible de gripe aviar A (H5N1) en viajeros con trastornos respiratorios importantes de causa desconocida, que hayan regresado al país hace poco tiempo tras visitar países afectados.

Sobre la base de análisis antigénicos de los virus de gripe aislados recientemente, datos epidemiológicos, estudios serológicos posvacunales y la disponibilidad de cepas de vacuna y reactivos, la vacuna trivalente contra la gripe recomendada para 2007-08 contiene cepas análogas a la A/Islas Salomón/3/2006 (H1N1), la A/Wisconsin/67/ 2005 (H3N2) y la B/Malasia/2506/2004. El único cambio en esta vacuna es el componente del virus A (H1N1). La cepa A/Islas Salomón/3/2006 es una variante antigénica reciente de la $\mathrm{A} / \mathrm{Nueva}$ Caledonia/20/99 usada en la vacuna 2006-07. (Centers for Disease Control and Prevention. Morb Mortal Wkly Rep. 2007;56(31):789-94.) 